\title{
Çolaklı (Elazığ) Çevresindeki Plütonik Kayaçların Mineralojik, Petrografik ve Jeokimyasal Özellikleri
}

\author{
Gizem ARSLAN ${ }^{1}$, Melahat BEYARSLAN ${ }^{* 1}$ \\ ${ }^{I}$ Fırat Üniversitesi, Mühendislik Fakültesi, Jeoloji Mühendisliği Bölümü, Elazığ
}

Geliş tarihi: 02.02.2016 Kabul tarihi: 11.05.2016

\begin{abstract}
Özet
İnceleme alanı, Çolaklı (ELAZIĞ) çevresinde yaklaşık $130 \mathrm{~km}^{2}$ 'lik bir alanı kapsamaktadır. Çalışma alanında yaşlıdan gence doğru Üst Kretase yaşlı Elazı̆̆ Magmatitleri, Orta Eosen-Üst Oligosen yaşlı Kırkgeçit Formasyonu, Üst Miyosen-Alt Pliyosen yaşlı Karabakır Formasyonu ve Pliyo-Kuvaterner yaşlı Palu Formasyonu yüzeylemektedir. Elazığ Magmatitleri inceleme alanında granit, granodiyorit, tonalit, diyorit ve kuvars diyorit gibi derinlik; mikrodiyorit ve aplit gibi yarı derinlik kayaçlarıyla temsil olunmaktadır. Elazığ Magmatitleri'ni uyumsuz olarak örten Kırkgeçit Formasyonu; kumtaşı ve marnlardan meydana gelmiştir. Kendisinden yaşı birimleri uyumsuz olarak örten Karabakır Formasyonu, inceleme alanında bazaltlardan oluşmaktadır. Karasal konglomeralardan meydana gelen Palu Formasyonu ise çalışma alanının en genç birimidir. Çalı̧̧a alanındaki asidik bileşimli kayaçlarda yapılan analiz sonuçlarına göre; bu kayaçlar magmatik seri olarak subalkalen karakterli ve I-tipi granitoyid özelliğinde olup, tektonik olarak ise, volkanik yay granitoyidleri (VAG) ve çarpışmayla eş yaşlı granitoyidleri (SynCOLG) alanında yer almaktadır. Elazı̆̆ Magmatitleri'ne ait olan Çolaklı (Elazı̆̆) çevresi plütonik kayaçları ada yaylarında oluşmuş yay magmatizması ürünüdürler.
\end{abstract}

Anahtar Kelimeler: Plütonik kayaç, Petrografi, Volkanik yay, Elazığ magmatitleri, Çolaklı, Elazı̆̆

\section{Mineralogical, Petrographical and Geochemical Characteristics of Plutonic Rocks in the Çolaklı (Elazı̆̆) Region}

\begin{abstract}
The studied area covers an area about $130 \mathrm{~km}^{2}$ in the Çolaklı (ELAZIĞ) environment. The units of studied area from the oldest to the youngest; Upper Cretaceous Elazığ Magmatics, Middle Eosen-Upper Oligocene Kırkgeçit Formation, Upper Miocene-Lower Pliocene Karabakır Formation and PlioQuaternary Palu Formation are exposed. In the studied area, the Elazığ Magmatics is represented by

\footnotetext{
"Yazışmaların yapılacağ1 yazar: Melahat BEYARSLAN, Fırat Üniversitesi Mühendislik Fakültesi, Jeoloji Mühendisliği Bölümü,Elazı̆̆, melahat.beyarslan@gmail.com
} 
plütonic rocks such as granite, granodiorite, tonalite, diorite, quartz diorite; subvolcanic rocks such as microdiorite and aplite. Kırkgeçit Formation covers an angular unconformity Elazığ Magmatics and this formation consists of sandstone and marls. Karabakır Formation comprising basalts overlap on older units with an unconformity. Palu Formation composed of terrestrial conglomerate is the youngest unit in the studied area. According to the geochemical analysis results, it defined that this magmatic rocks have subalkaline characteries and I-type granitoid plotted volcanic arc granitoids (VAG) and syn-collision granitoids (Syn-COLG). The intrusive rocks in studied area belong to Elazığ Magmatics are products of island arc magmatism.

Keywords: Plutonic rock, Petrography, Volcanic arc, Elazig magmatics, Çolaklı, Elazı̆

\section{GíRiş}

$\mathrm{Bu}$ çalışma ile Elazı̆ ili kuzeyinde yüzeyleyen Çolaklı çevresi plütonik kayaçların mineralojik, petrografik ve jeokimyasal özelliklerinin incelenmesi amaçlanmıştır. Çalışmanın konusu Elazığ Magmatitleri'ne ait olan Çolaklı (Elazığ) çevresi plütonik kayaçlarını sınıflandırmak ve jeokimyasal özelliklerinden yararlanarak magmanın kökenini ve jeotektonik ortamını belirlemektir.

\section{2. ÖNCEKİ ÇALISSMALAR}

Bölgenin ekonomik değere sahip cevherleşmeler açısından zengin oluşu, bölgesel ölçekli yapısal unsurların (Kuzey Anadolu Fayı, Doğu Anadolu Fayı) varlığı, büyük mühendislik yapılarının (Keban, Karakaya Barajları gibi) varlığı ve bölgenin jeotektonik evrimini açıklamaya katkısı olabilecek magmatik kayaçların geniş yüzeylemeler sunması, jeolojik açıdan bölgenin önemini artırmıştır. Tüm bu unsurları bir arada taşıyan bölge gerek Türk, gerekse yabancı birçok yer bilimcinin dikkatini çekmiş ve bölgede değişik amaçlı birçok çalışmanın yapılmasına temel oluşturmuş̧ur. Perinçek [1], bölgesel ölçekte yaptığı çalışmalarda Doğu Toros Orojenik Kuşağı'nda yüzeyleyen birimlerin dağılımını, konumunu, petrografi, petroloji ve stratigrafisini değişik zaman aralıklarında değişik bölgelerde incelemiştir. Araştırmacı, elde ettiği bulgulara dayanarak, bu kuşağın tektonik evrimini levha tektoniği kuramıyla irdelemiştir. Bingöl [5],
Elazı̆̆-Pertek-Kovancılar çevresinde yaptı̆̆ çalışmalarda, Yüksekova Karmaşı̆̆ı (Elazığ Magmatitleri)'nın petrografi ve petrolojisini inceleyerek, karmaşı̆̆ın oluşum ortamını açıklamaya çalışmıştır. Araştırmacı, Yüksekova Karmaşı ğı (Elazığ Magmatitleri)'nı kalkalkali bir magmadan türemiş ada yayı ürünü olarak değerlendirmiş ve karmaşığın Üst Kretase sonu tektonik hareketler ile, Keban Metamorfitleri tarafından üzerlendiğini belirtmiştir. Bingöl [7], Yüksekova Karmaşı̆̆ı (Elazığ Magmatitleri)'nı oluşturan kayaçların gabrodan granite kadar geniş bir bileşim farklılığı sunduğunu ve bu kayaçların dalma-batma olaylarının üç evresinde oluştuğunu belirtmiştir. Araştırmacı, birinci ve ikinci evrede ada yayı kayaç topluluğunu karakterize eden gabro, diyorit, monzonit, tonalit ve granodiyoritlerin oluştuğunu; üçüncü evrede ise kıta-ada yayı çarpışma zonunu karakterize eden granitlerin oluştuğunu belirtmiş̧ir. Turan [8], Baskil-Aydınlar yöresinde yaptı̆̆ 1 çalışmada Yüksekova Karmaşı̆̆ı'nın, Neotetis'in güney kolu üzerinde Senoniyen süresince hüküm süren dalmabatma zonunda oluşmuş ada yayı ürünleri olduğunu açıklamıştır. Akgül [9], Piran Köyü (Keban) çevresinde Yüksekova Karmaşı̆̆ Magmatitleri) üzerinde yaptı̆̆ 1 petrografik ve petrolojik çalışmada karmaşı̆̆ oluşturan kayaçların bölgeye üç farklı evrede yerleştiğini; birinci evrede bazik plütonik ve volkanik kayaçların, ikinci evrede asit plütonik ve volkanik kayaçların, üçüncü evrede ise artık magmadan türeyen aplit ve lamprofirlerin geliştiğini belirtmiștir. Turan [10], Elazığ yakın çevresindeki tektonik yapıları ve bunların bölgenin jeolojik evrimindeki yerini açıklamıştır. Yazar, bölgenin 
orojenik kuşaklara özgü kıvrımlı ve özellikle kırıklı türden yapılar bakımından oldukça zengin olduğunu ve bu yapıların Neotetis'in güney kolunun Üst Kretase-Alt Miyosen arasındaki kapanma ve sonuçta Orta Miyosen'deki nihai kıtakıta çarpışmasına bağlı sıkışma rejimi altında meydana geldiğini belirtmiştir. İnceöz [11], Harput (Elazığ) yakın kuzeyi ve doğusunda yaptığ çalışmada; inceleme alanında görülen değişik litolojilerdeki kayaçların birbiriyle olan ilişkilerini belirlemiş, bölgenin 1/25.000 ölçekli harita düzeyinde ayrıntılı tektonik yapıları ortaya çıkarıp, bu yapılardan yararlanarak bölgenin tektonik evrimine yorum getirmiştir. Kürüm [12], Elazı ̆̆ kuzeybatısındaki genç volkanitlerin petrolojik özelliklerini incelemiş ve çalışma bölgesindeki volkanizmanın Üst Miyosen'de kalkalkalen özellikte, daha sonra çok az oranda toleyitik ve en son aşamada da önemli ölçüde alkalen özellikte olduğunu belirtmiştir. Bingöl ve Beyarslan [13], Elazı ̆ Magmatitleri’nin petrografisini ve jeokimyasını incelemişlerdir. Araştırmacılar, arazi ve jeokimyasal verilere dayanarak; Elazığ Magmatitleri'ni oluşturan kayaçların Üst Triyas'tan itibaren açılmaya başlayan Neotetis'in güney kolunun Üst Kretase'den itibaren kuzeye doğru dalımı ve buna bağlı olarak üstteki levhada meydana gelen supra-subduction zonu ofiyolitleri (Kömürhan Ofiyoliti) üzerinde gelişen kalkalkalen seriye ait ve ada yayı magmatizması ürünleri olduğunu belirtmişlerdir.

Beyarslan [14], Serince-Harput çevresindeki granitik kayaçları ve kökenlerini incelemiştir. İnceleme alanındaki granitik kayaçlar Elazı ğ Magmatitleri'nin diyorit ve tonalitleri içerisinde intrüzif kütleler halinde bulunurken, volkanit ve volkanoklastitleri içerisinde dayk ve siller halinde görülmektedir. İnceleme alanı doğusunda ise Elazı̆̆ Magmatitleri'nin üzerinde geliştiği okyanus kabuğuna ait gabro ve diyabazları kesmektedir.

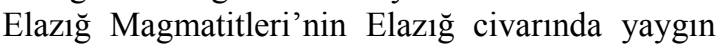
biçimde yüzeyleyen ve yitim zonu üzerindeki levhada açılmaya bağlı (SSZ) olarak gelişen ofiyolitler (Guleman, Kömürhan, İspendere) üzerinde oluşmuş tipik ada yayı malzemesi olduğu kabul edilmiştir.

\section{METERYAL VE METOD}

Çalışmalar, literatür, arazi, laboratuvar ve büro çalışmaları olmak üzere dört aşamada gerçekleştirilmiştir. İnceleme alanının 1/25.000 ölçekli haritası İnceöz (1994) tarafından yapıldığından, ayrıca haritalama çalışması yapılmamış ve bu haritadan çalışmalarımızda yararlanılmıştır [11]. Arazi çalışmaları sırasında birimlerin birbiriyle olan ilişkileri araştırılıp, petrografik ve jeokimyasal incelemeler için çok sayıda örnek alınmıştır. Alınan kayaç örneklerinden; laboratuvarda petrografik ince kesitler hazırlanmış, yapılan bu kesitler polarizan mikroskopta incelenerek mineralojik ve petrografik özellikleri belirlenmeye çalışılmıştır. Petrografik olarak incelenmiş örneklerden jeokimyasal analizler yapılması için daha az altere olan örnekler seçilmiş ve bunlardan analiz yaptırılmıştır.

Analizler Canada ACME analitik laboratuarında ICP-MS yöntemi ve Canada ACTLAB'da TritonMC (Mass Spectrometer) yöntemi kullanılarak yaptırılmıştır. Arazi ve laboratuvar çalışmalarından sonra elde edilen veriler değerlendirilerek inceleme alanındaki plütonik kayaçların kökeni, oluşum ortamları ve oluşum şartları belirlenmiştir.

\section{GENEL JEOLOJİ}

Çolaklı plütonik kayaçları Elazığ ilinin kuzeyinde, Keban Baraj Gölünün güneyinde yüzeylemektedir (Şekil 1). Bu bölgede yüzeyleyen plütonik kayaçlar granit grubu kayaçlar ve diyorit grubu kayaçlar olmak üzere iki birime ayrılırlar.

Diyorit grubu kayaçlar plütonik kayaçlarının tabanını oluşturmakta ve granit grubu kayaçlar tarafindan kesilmektedir. Her ikigrup kayaç uyumsuz olarak Orta Eosen-Oligosen yaşl1 Kırgeçit Formasyonu, Üst Miyosen-Alt Pliyosen yaşlı Karabakır Formasyonu, Pleistosen yaşlı Elazığ volkanitleri, Pliyo-Kuvaterner yaşlı Palu Formasyonu ve güncel alüvyonlarla örtülmektedirler (Şekil 2). 


\subsection{Elazı̆ Magmatitleri}

Elazı̆̆ civarında ve çalışma alanında geniş bir yüzeylemeye sahip olan, ilk defa Perinçek $[1,2]$ tarafından Hakkari ili Yüksekova ilçesi yakınlarında Yüksekova Karmaşı̆̆ı adıyla tanımlanan ve Hakkari'den başlayarak Kahramanmaraş'a kadar yayılım gösteren birimin devamı olan Elazığ Magmatitleri pek çok araştırmacı tarafindan çalışılmıştır. Oldukça geniş bir alanda yüzeyleme sunan birim, litolojik özellikleri bakımından bölgesel farklılıklar göstermektedir. İşte bu bölgesel farklılıklardan yola çıkan araştırmacılar Yüksekova Karmaşı̆̆ı'nın Elazı ğ çevresinde daha düzenli bir istif sunduğunu belirtip, birimin Elazı̆̆ çevresindeki yayılımı için bu adlamanın daha uygun olacağını düşünmüşlerdir. Bölgesel farklılıklar bir yana birakılacak olursa Elazığ Magmatitleri çoğunlukla gabro, diyabaz, diyorit, monzonit, tonalit, granodiyorit, granit, bazalt, andezit, piroklastit ve pelajik sedimentlerden oluşmaktadır [11]. Elazı̆̆ ve çevresinde magmatitler üzerinde ayrıntılı petrografik ve petrolojik incelemeler yapan Bingöl [5] karmaşı̆̆ın genel olarak gabro, diyorit, monzonit, tonalit ve granodiyorit gibi derinlik kayaçları; bazalt, andezit, dasit ve genellikle andezitik piroklastitler ve tüm bunları kesen granitik kayaçlar ve volkanosedimanlardan oluştuğunu belirtmektedir. Yazar, birimin bu şekilde düzenli bir istif göstermesinden dolayı Yüksekova Karmaşı̆̆ı'ndan farklı olduğunu belirtip, "Elazığ Magmatitleri" olarak adlandırmıştır. Bingöl ve Beyarslan [13], Elazı̆̆ Magmatitleri'nin birbirini kesen diyorit, tonalit, granodiyorit ile bunlar üzerinde yer alan bazaltik yastık lavlar, bazaltik-andezitik lav akıntıları, andezitik piroklastitler, volkanosedimanlar ve tüm derinlik ve yüzey kayaçlarını kesen granit dayk ve intrüzyonları, andezitik lav ve piroklastitler ile volkanosedimanları kesen dasit daykları ve dasit domlarından oluştuklarını kabul etmektedirler.

Birçok araştırmacı (Perinçek ve Özkaya, [15]; Turan, [8]; Turan ve Bingöl, [16]; Bingöl, [5, 6, 7]; Beyarslan, [17]; Bingöl ve Beyarslan, [18]; Beyarslan, [19])birimin yaşını Üst Kretase ve/veya Senoniyen olarak değerlendirmişlerdir. Elazı̆̆
Magmatitleri'nin oluşumu hakkında değişik araştırmacılar aynı veya birbirine yakın görüşler ileri sürmüşlerdir. Bingöl [5], magmatitlerin kısmen okyanusal kısmen de kitasal kabuk üzerinde gelişen ada yayı ürünleri olduğunu belirtmiştir. Yazgan [20], birimin alkaliye eğimli kalkalkalen özellikte olduğunu ve bir kita kenarı magmatizması ya da kısmen okyanusal kabuk üzerinde gelişmiş bir ada yayı ürünü olarak yorumlamıştır. İnceleme alanında Elazı̆̆ Magmatitleri; granitik kayaçlar ve diyorit grubu kayaçlar olmak üzere iki birime ayrılmış ve incelenmiştir.

\subsubsection{Granitik Kayaçlar}

Kızıldağ, Karadağ ve Serince ve Çolaklı köyleri çevresinde yüzeylemeler sunmaktadır (Şekil 1). Genellikle açık pembe renkli kayaçlar granitten tonalite kadar değişen bileşime sahiptirler. Arazide bu litolojik birimleri birbirinden ayırmak mümkün değildir. Bol çatlaklı, ileri derecede ayrışmış yüzeylere sahiptirler. $\mathrm{Bu}$ kayaçlar kalınlıkları milimetreden santimetreye kadar değişen felsik (aplitik) dayklar ve diyorit daykları tarafindan kesilmektedirler (Şekil 3). İncelenen granitik kayaçların en önemli özelliklerinden biriside içermiş oldukları mafik mikrogranüler anklavlardır. $\mathrm{Bu}$ tür anklavlar genellikle oval, merceksi ve elipsoidal şekilli olup, birkaç santimetre büyüklüğündedirler. İçerisinde bulunduğu granitik kayaçla herhangi bir reaksiyon göstermemektedirler (Şekil 4).

\subsubsection{Diyorit Grubu Kayaçlar}

Diyorit grubu kayaçlar, Kızıldağ'ın batı ve kuzeybatısında, Meşeliköy çevresinde, Yılangeçiren Köyü’nün doğu ve batısında, Obuz Köyü'nün güney ve doğusunda yüzeylemektedirler. Yüzlekler altere olmuş yüzeylere sahiptir. Genellikle gri renkli, hafifçe yeşilimtırak renklidirler (Şekil 5). Arazide diyorit grubunu oluşturan farklı litolojik birimleri mineralojik ve dokusal olarak ayırmak imkansızdır. Ayrıca, bazı bölgelerde özellikle mafik minerallerin oranlarındaki artışlar gözlenebilmektedir. 

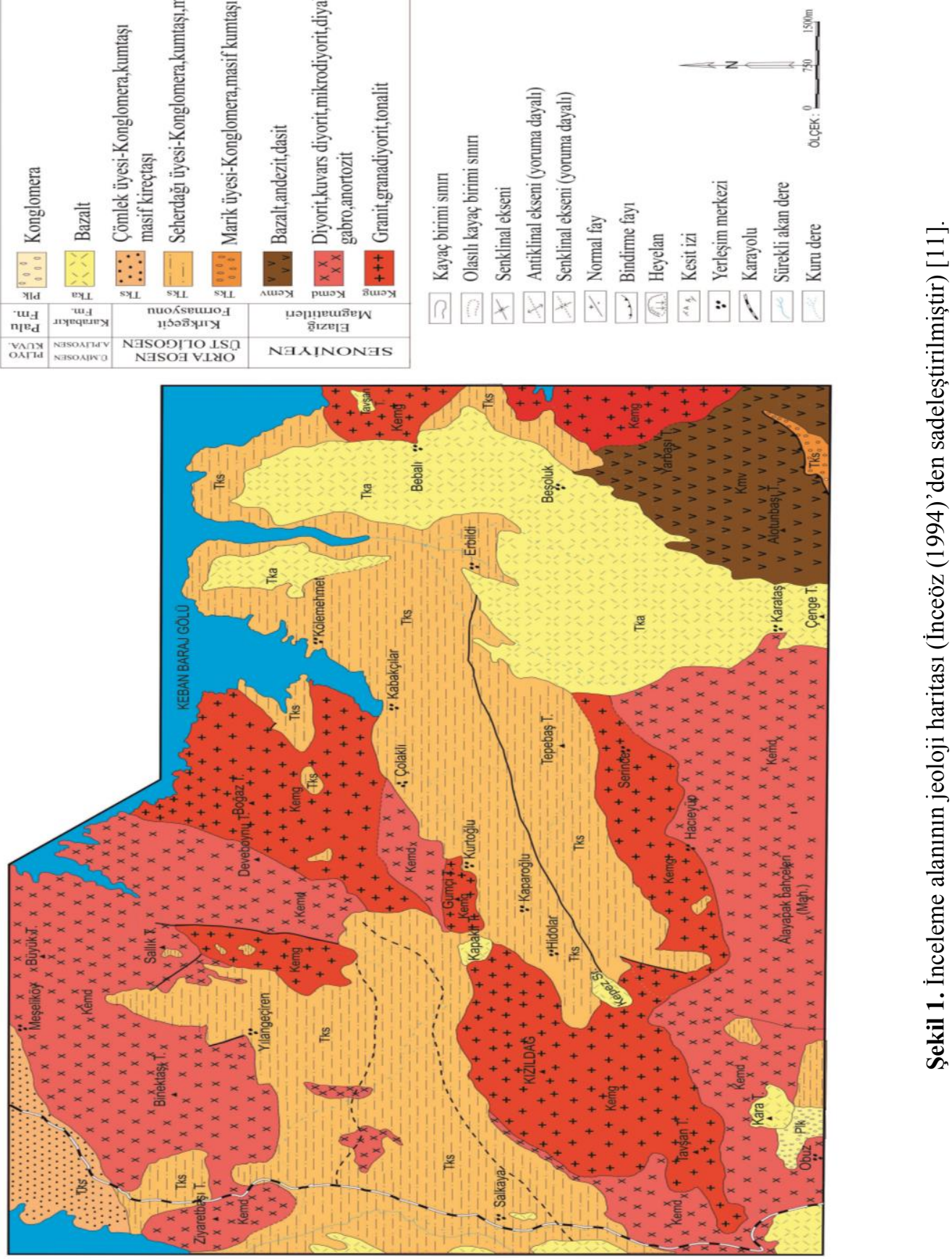


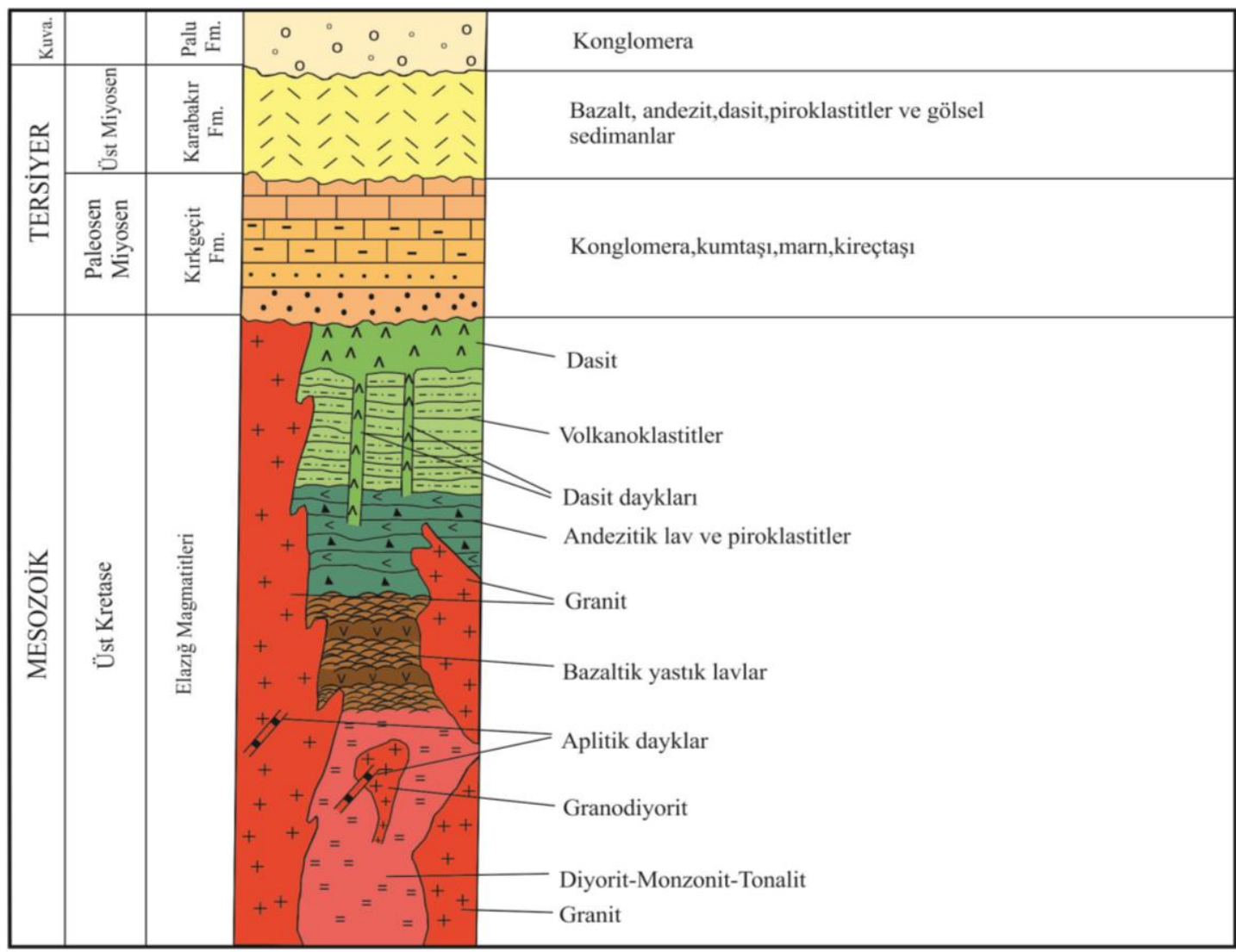

Şekil 2. İnceleme alanındaki birimler arasındaki ilişkileri gösteren genelleştirilmiş stratigrafik kesit ([13]'dan değiştirilerek alınmıştır).

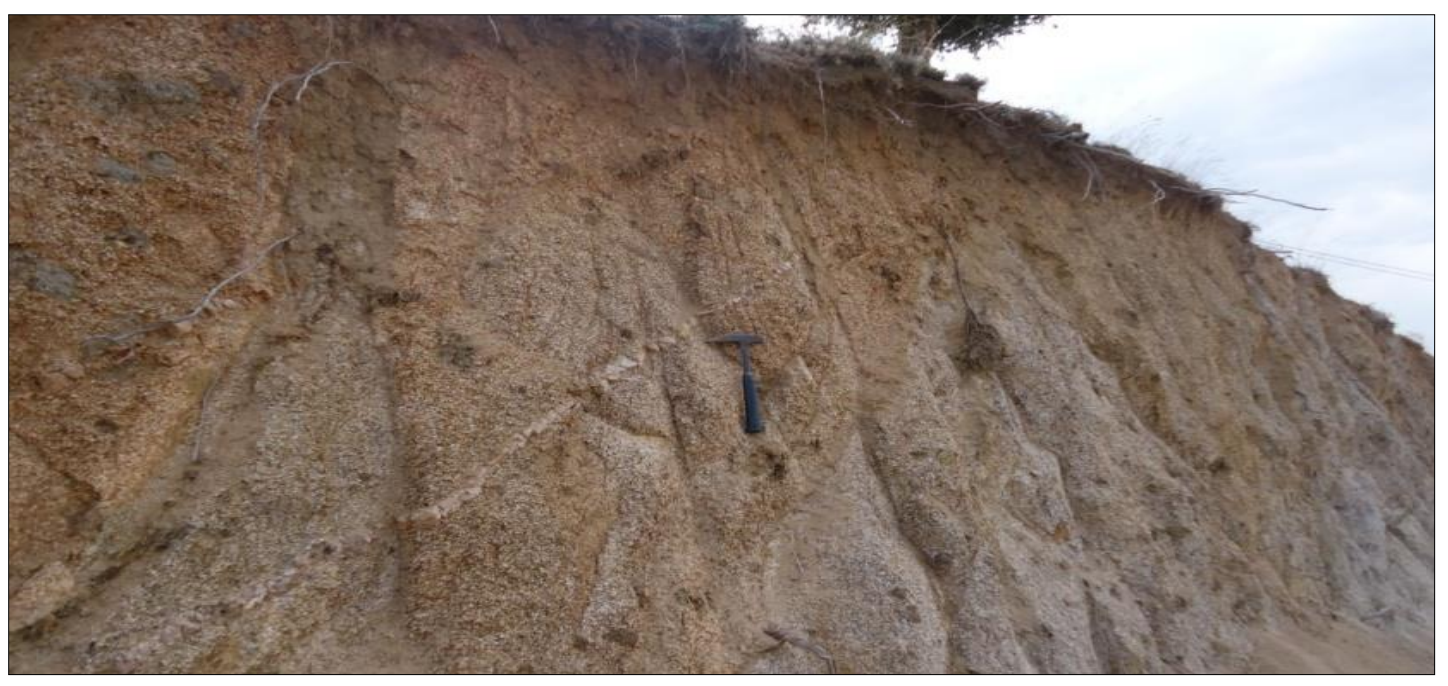

Şekil 3. Elazı ̆̆ Magmatitleri’ ne ait granitik kayaçlardaki aplitik damarlar ve arenalar (37S 0525271D/4290362K) 


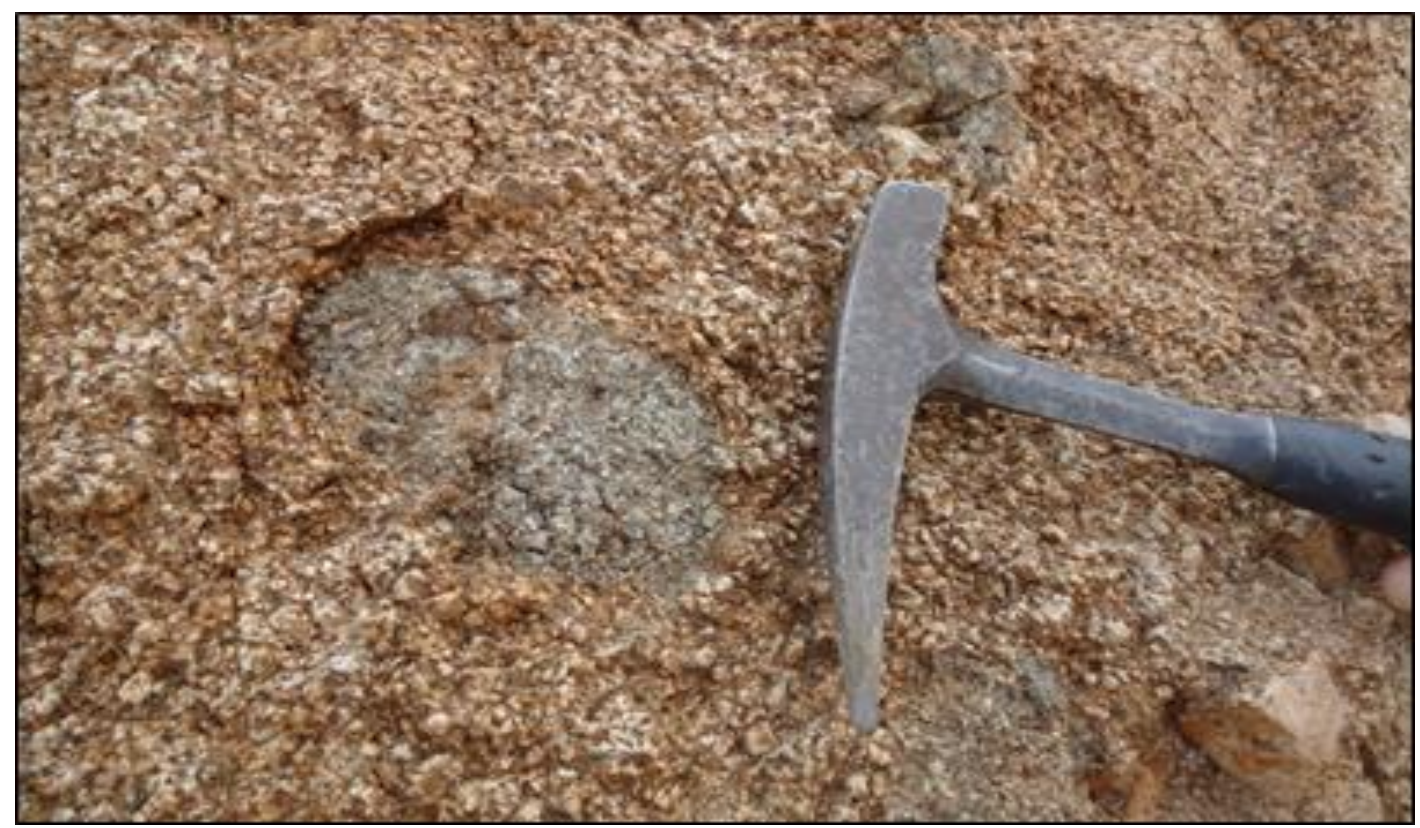

Şekil 4. Elazı̆g Magmatitleri'ne ait granitik kayaçlar içerisindeki anklavlar (37S 0525271D/4290362K)

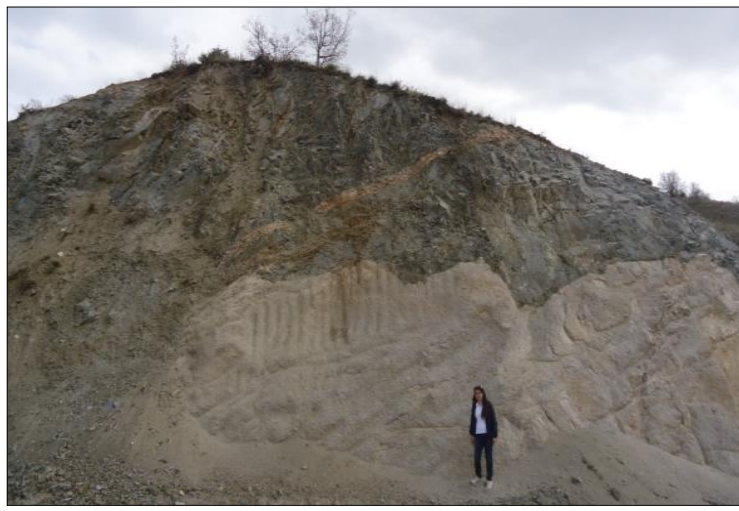

Şekil 5. Elazı ̆̆ Magmatitleri'ne ait granitik kayaçlar ile diyorit grubu kayaçlar arasındaki intrüzif dokanak $(37 \mathrm{~S}$ 0525822D/4289834K)

\section{PETROGRAFi}

\subsection{Diyorit Grubu Kayaçlar}

İnceleme alanında geniş bir yayılım gösteren diyorit grubu kayaçlar diyorit, kuvars diyorit ve damar kayaçlarından oluşmaktadır. Esas olarak plajiyoklas ve hornblendlerden oluşan kayaç az oranda da kuvars ve opak mineral içermektedir. Diyoritlerde plajiyoklaslar, özşekilli ve yarı özşekilli kristaller halindedir. Genel olarak plajiyoklaslarda albit, albit+karlsbad türü ikizlenmeler görülmekle birlikte, ezilme zonu yakınından alınan örneklerdeki ikizlenmelerinde deformasyondan dolayı bükülmeler ve silinmeler gösteren kristaller de vardır. $\mathrm{Bu}$ durum düşük dereceli metamorfizma koşullarına işaret etmektedir. Ayrica, plajiyoklaslarda karbonatlaşma, sosuritleşme türü alterasyonlar görülmektedir. Plajiyoklaslar kayaç içerisinde yaklaşık olarak \%60-65 oranında bulunmakta olup, albit ikizine göre yapılan sönme açısı tayinlerinde plajiyoklas türü andezin olarak belirlenmiştir. Hornblend mineralleri yarı özşekilli ve özşekilsiz kristaller halinde olup, yeşilimsi tonlarda bir pleokroizmaya sahiptirler. Diyorit grubu kayaçlar içerisinde bulunan kuvars diyoritler, mineralojik ve optik özellikleri bakımından diyoritlere benzemektedirler. Ancak, arazide dağılımları tam 
olarak belirlenememekle birlikte kuvars oranındaki artış dikkate alınarak kuvars diyorit olarak tanımlanmışlardır. Diyoritlerden farklı olarak daha fazla oranda opak mineral içeren bu kayaçlardaki kuvarslar genellikle özşekilsiz kristaller halinde, dalgalı sönmelidirler ve $\% 5$ 'ten fazla orana sahip oldukları için bu kayaçlar kuvars diyorit olarak isimlendirilir. Kuvars diyoritlerde plajiyoklaslar, özşekilli ve yarı özşekilli kristaller halindedir. Genel olarak plajiyoklaslarda albit, albit+karlsbad türü ikizlenmeler gözlenmektedir. Kuvars diyoritlerde görülen hornblendler, genellikle yarı özşekilli ve özşekilsiz kristaller halindedir. Az oranda da iri taneli özşekilli kristallere de rastlanmaktadır. Bunlar yeşilimsi tonlarda pleokroizmaya sahiptirler. Tektonizmaya bağlı olarak düşük dereceli metamorfizmanın izlerini taşımaktadırlar. $\mathrm{Bu}$ sebeple iri hornblend kristalleri içerisinde lifsi tremolit-aktinolit kapantıları görülmektedir. Ayrıca, bu kristallerin çevresi yoğun bir şekilde opak mineraller ile sarılmıştır. Diyorit grubu kayaçlar içerisinde, diyoritlerden farklı renklere sahip ve diğer diyoritik kayaçları kesen daha ince taneli mikrodiyoritlere de rastlanmaktadır. Bunlarda diyoritlerle aynı mineralojik petrografik özelliklere sahip olup, daha ince tanelidirler. Diyorit grubu kayaçlarda genel olarak subhedral granüler doku görülmekle birlikte, ayrıca poikilitik dokuya da rastlanmaktadır (Şekil 6). Poikilitik dokuda büyük boy amfibol kristalleri bulunmaktadır ve bu amfibol kristalleri içerisinde farklı mineraller olarak opak mineraller ve plajiyoklaslar küçük boy kristaller şeklinde görülmektedir.

\subsection{Granit Grubu Kayaçlar}

Granit Grubu Kayaçlar, çalışma alanında geniş bir yayılım sunan granit, granodiyorit ve tonalit bileşimli kayaçlardan oluşmaktadır.

\subsubsection{Granitler}

Granitler esas olarak kuvars, plajiyoklas, K-feldispat, biyotit, amfibol ve opak minerallerden oluşmaktadır. Granitler içerisindeki kuvarslar değişik boyutlu olup, özşekilsiz kristaller halindedir ve deformasyondan kaynaklanan dalgalı sönme gösterirler. Ayrıca, diğer minerallerin ara boşluklarını doldurmaktadırlar ve kayaç içerisinde yaklaşık \%20-25 civarında bir orana sahiptirler. Kayaç içerisindeki plajiyoklaslar, özşekilli ve yarı özşekilli kristaller halindedir. Yoğun olarak albit, albit+karlsbad ikizi gösteren plajiyoklaslardaki alterasyon etkileri sonucunda serizitleşme, sosuritleşme ve karbonatlaşma görülmektedir. Serizit mineralleri ince pulcuklar halinde gelişmiş olup, yer yer mineral içerisinde dağılmış bir şekilde bulunmaktadır. Albit ikizi gösteren kristallerde $8^{\circ}-15^{\circ}$ lik sönme açılarına göre plajiyoklasların albit-oligoklaz türünde olduğu saptanmıştır. Plajiyoklaslar, kayaç içerisinde yaklaşık olarak \%30-35 oranında bulunmaktadırlar. Granitler içerisinde bulunan Kfeldispatlar oldukça iri taneli, genellikle özșekilsiz veya yarı özşekilli kristaller halinde olup, ikizlenmelerine dayanarak bunların ortoklas bileşiminde olduğu söylenebilir. Bazı kristallerde çok belirgin olmasa da ince dilinim izlerine rastlanmaktadır. Ayrıca yoğun altereli olup, büyük bir kısmı pertitik özellik gösteren alkali feldispatlarda yer yer karbonatlaşma görülmektedir. Kayaç içerisinde alkali feldispatların oranı yaklaşık \%25-30 civarındadır. Mafik mineral olarak biyotit ve amfibol mineralleri bulunmaktadır. Kayaç içerisinde \% 5-10 oranında bulunmaktadırlar. Biyotitler, levhamsı-prizmatik ve çubuksu kristaller halindedir; ancak tamamen oksitlenmişlerdir. Tek yönde dilinimi, kahverengi pleokroizması ve D-B yönünde en karanlık durumunu alması ile diğer minerallerden ayrılırlar. Biyotitlere oranla daha az bulunan amfiboller, yeşilimsi pleokroizmaya sahip olup, yarı özşekilli veya özşekilsiz kristaller halindedir.

Yer yer kloritleşme izlenmektedir. Bunlardan başka tali olarak yer yer boşlukları dolduracak şekilde opak mineraller görülmektedir. Granitlerde genellikle özşekilli, yarı özşekilli ve özşekilsiz kristallerin oluşturduğu subhedral granüler doku (Şekil 7) ve K-feldispatlar ile kuvarsların iç içe büyüme gösterdiği grafik doku izlenmektedir.

\subsubsection{Granodiyoritler}

Granodiyoritler, esas olarak plajiyoklas, kuvars, Kfeldispat, biyotit ve amfibol; ikincil bileşen olarak da klorit, çok az miktarda opak mineralden oluşmaktadır. Granodiyoritlerde plajiyoklaslar 


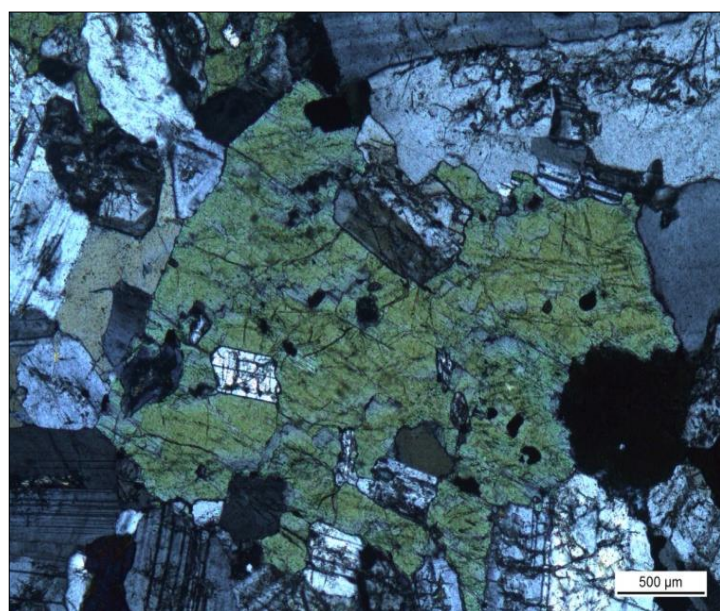

Şekil 6. Elazı ̆̆ Magmatitleri'nin diyorit grubu kayaçlarının gösterdiği poikilitik doku (4x/0,10 büyütmeli objektif Çift Nikol)

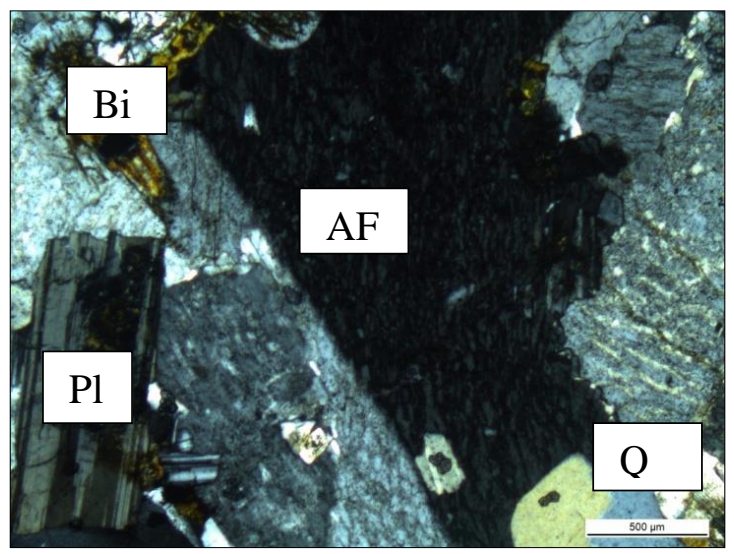

Şekil 7. Granitlerdeki subhedral granüler doku ve alkali feldispat minerallerinde pertitleşme (Q: Kuvars, A.F: Alkali Feldispat, Pl: Plajiyoklas, Bi: Biyotit. 4x/0,10 büyütmeli objektif Çift Nikol)

özşekilsiz ve yarı özşekilli kristaller halinde olup, çoğunlukla normal zonlanma göstermektedirler. Ayrıca albit+karlsbad ikizi gösteren plajiyoklas kristallerine de rastlanmaktadır. Plajiyoklaslarda, karbonatlaşma, serizitleşme türü alterasyonlar görülmektedir. Plajiyoklaslar, kayaç içerisinde yaklaşık \%50-55 civarında bulunmaktadır. Granodiyoritler içerisindeki kuvarslar genellikle özşekilsiz kristaller halinde olup, deformasyon geçirmiş olanlar dalgalı sönme göstermektedirler. Kayaç içerisindeki oranları yaklaşık \%20-25 civarındadır. Kayaç içerisinde az oranda bulunan K-feldispatlar çoğunlukla iri kristalli olup, pertitik yapı gösteren yarı özşekilli veya özşekilsiz kristaller halinde bulunmaktadır. Kayaç içerisinde \%15-20 civarında bulunmaktadırlar. Mafik mineral olarak bulunan biyotit ve hornblendler ise, değişik boyut ve şekillerde olup, yer yer kenarları boyunca kloritleşmişlerdir. Granitlere oranla hornblend oranlarında artış gözlenmektedir. Opak mineraller ise, daha az oranda bulunmaktadir. Granodiyoritlerde genelde subhedral granüler doku görülmektedir (Şekil 8). Az oranda grafik dokuya da rastlanmaktadır.

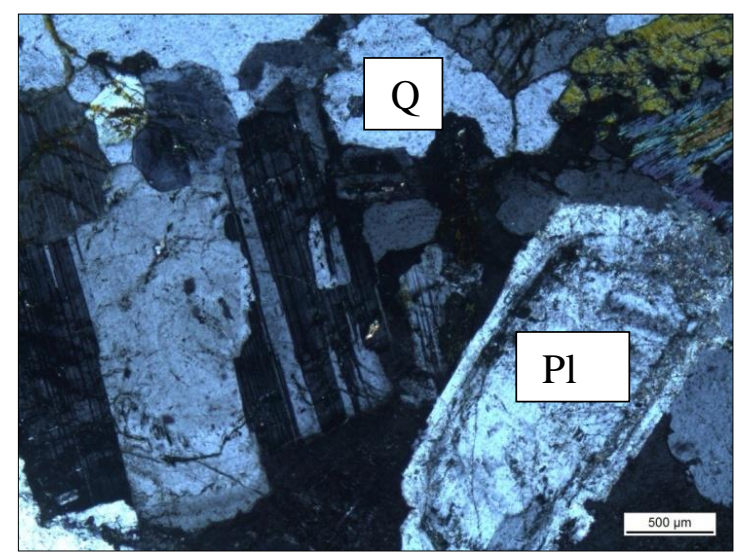

Şekil 8. Elazı̆̆ Magmatitleri'nin granitik kayaçlara ait granodiyoritlerin gösterdiği subhedral granüler doku (Q: Kuvars, Pl: Plajiyoklas. 4x/0.10 büyütmeli objektif Çift Nikol)

\subsubsection{Tonalitler}

Granitik grubu kayaçlar içerisinde yer alan tonalitler, esas olarak plajiyoklas, kuvars, hornblend ve biyotit; az oranda da opak minerallerden oluşmaktadır. Tonalitlerde plajiyoklaslar özşekilli ve yarı özşekilli kristaller halindedir. Yaygın olarak albit, albit+karlsbad ikizlenmesi göstermelerine rağmen, normal zonlu yapıya sahip kristaller de bulunmaktadır. Plajiyoklas kristallerinde albit ikizine göre yapılan sönme açısı tayinlerinde $13^{\circ}-22^{\circ}$ lik sönme açılarına sahip oldukları ve plajiyoklas türü 
An 29-42 bileşimine sahip olup, oligoklas-andezin türünde olduğu saptanmıştır. Alterasyon türü olarak sosuritleşme ve serizitleşme görülmektedir. Kayaç içerisinde plajiyoklaslar, yaklaşık \%55-65 civarındadır. Kayaç içerisinde \%20-25 gibi bir orana sahip olan kuvarslar, genellikle özşekilsiz ve yarı özşekilli olup, ara boşlukları dolduran kristaller halinde bulunmaktadırlar ve dalgalı sönme gösterenlerine de rastlanmaktadır. Mafik bileşen olarak bulunan hornblendler ise, yeşil renkte pleokroizmasıyla tanınmaktadır ve özşekilsiz veya yarı özşekilli kristaller halindedirler. Kayaç içerisinde \%15-20 civarında bir orana sahiptirler. Tonalitlerde yaygın olarak özşekilli, yarı özşekilli ve özşekilsiz kristallerin oluşturduğu subhedral granüler doku gözlenmektedir (Şekil 9).

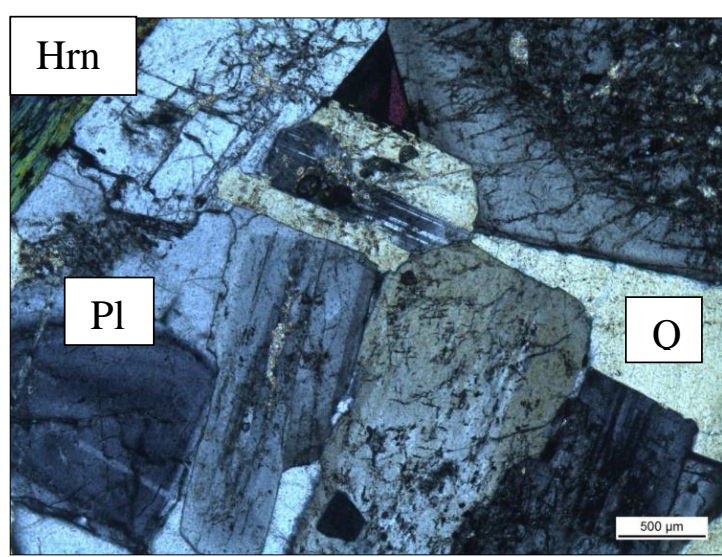

Şekil 9. Elazı̆̆ Magmatitleri’nin granitik kayaçlara ait tonalitlerdeki subhedral granüler doku (Q: Kuvars, Pl: Plajiyoklas, Hrn: Hornblend. $4 \times / 0.10$ büyütmeli objektif. Ç.N.)

\section{JEOKIMMYASAL ÖZELLIKKLER}

\subsection{Ana Oksit, İz element ve Nadir Toprak Element Jeokimyası}

Çalışma konusunu oluşturan Çolaklı (Elazığ) çevresindeki Elazı̆̆ Magmatitleri’ni kimyasal olarak sinıflandırmak ve jeokimyasal özelliklerinden yola çıkarak, magmanın kökenini ve tektonik oluşumunu belirlemek amaciyla asidik bileşimli 16 adet örneğin kimyasal analizleri yaptırılmıştır. Analizler, Canada ACME analitik laboratuarlarında ICP-MS (Inductively Coupled Plasma Mass Spectrometer) yöntemi kullanılarak yapılmıştır. Magmatik kayaçların majör ve iz element içeriklerini belirleyen temel etken magmanın türediği kaynağın bileşimi ve oluşumu sırasında geçirdiği süreçlerdir. $\mathrm{Bu}$ amaçla jeokimyasal verilerden yararlanarak çalışma konusu kayaçların türleri, magmanın türü, kimyasal özellikleri ve oluşum ortamı ile bölgenin jeotektoniğinin ortaya konulması amaçlanmıştır.

Analizi yaptırılan örneklerin ana element oksit bileşenleri, iz element ve Nadir Toprak Tlement içerikleri Çizelge 1'de verilmiştir: Oksit değerlerinden elde edilen sonuçların mikroskopta yapılan petrografik incelemelerle uyum sağladığ1 QAP diyagramında görülmektedir (Şekil 10).

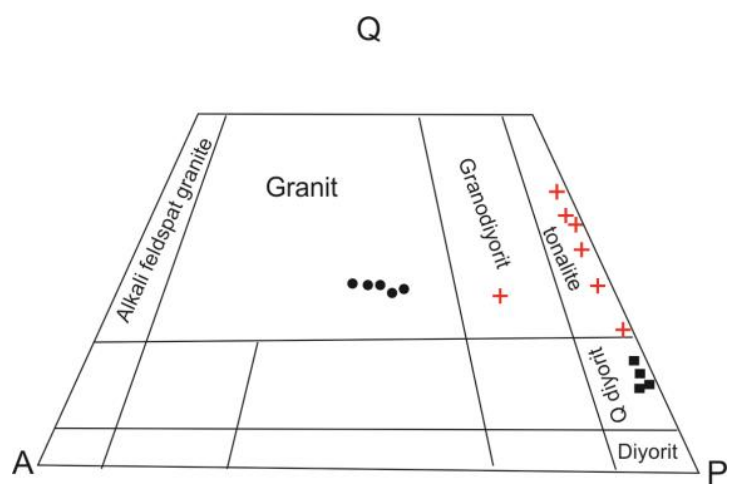

Şekil 10. Elazı̆̆ Magmatitleri'ne ait örneklerin normatif bileşenlerine göre QAP diyagramında gösterimi

Debon ve Le Fort [21, 22] tarafindan önerilen ve kayaç oluşturucu ana felsik minerallerin (kuvars, plajiyoklas, K-feldispat) ana element içeriklerine dayalı Q-P diyagramına göre 6 örnek tonalit alanına, 5 örnek granit alanına, 4 örnek kuvars diyorit alanına ve 1 örnek de granodiyorit alanına düşmektedir (Şekil 11). Örneklerin dağılımları incelendiğinde ince kesitlerle ve normatif bileşenlerle uyum sağladıkları görülmektedir. Magmatik kayaçlar, seri karakteri açısından genel olarak subalkalen, alkalen ve peralkalen kayaç serileri adı altında incelenirler. Bunlardan subalkalen kayaç serileri de kalkalkalen ve toleyitik serilere ayrılırlar. İnceleme alanındaki 
Çizelge 1. Elazı ğ Magmatitleri'ne ait kayaçların ana oksit, iz element ve nadir toprak element içerikleri

\begin{tabular}{|c|c|c|c|c|c|c|c|c|c|c|c|c|c|c|c|c|}
\hline ÖRNEK ADI & GA-3 & GA-9 & GA-12 & GA-13 & GA-14 & GA-15 & BA-1 & BA-2 & BA-6 & BA-7 & BA-8 & BA-14 & GB-3 & GB-4 & GB-13 & GB-15 \\
\hline \multicolumn{17}{|l|}{ Ana Oksit } \\
\hline $\mathrm{SiO}_{2}$ & 73,7 & 65,16 & 73,26 & 53,39 & 55,15 & 58,57 & 74,3 & 73,35 & 74,91 & 52,18 & 48,43 & 71,08 & 50,68 & 72,88 & 73,93 & 71,46 \\
\hline $\mathrm{TiO}_{2}$ & 0,09 & 0,34 & 0,09 & 0,4 & 0,4 & 0,4 & 0,07 & 0,10 & 0,04 & 0,64 & 0,59 & 0,30 & 0,69 & 0,31 & 0,21 & 0,36 \\
\hline $\mathrm{Al}_{2} \mathrm{O}_{3}$ & 13,75 & 16,27 & 13,79 & 15,36 & 15,43 & 13,37 & 13,59 & 13,97 & 13,71 & 17,71 & 14,46 & 14,89 & 19,65 & 14,05 & 12,14 & 14,52 \\
\hline $\mathrm{Fe}_{2} \mathrm{O}_{3}$ & 1,60 & 4,65 & 1,79 & 7,20 & 7,23 & 6,99 & 1,47 & 1,50 & 0,80 & 9,62 & 10,70 & 3,09 & 9,38 & 2,99 & 3,15 & 3,10 \\
\hline MnO & 0,03 & 0,09 & 0,01 & 0,14 & 0,15 & 0,17 & 0,01 & 0,03 & 0,29 & 0,18 & 0,2 & 0,03 & 0,18 & 0,03 & 0,03 & 0,07 \\
\hline MgO & 0,04 & 1,47 & 0,07 & 9,22 & 7,41 & 7,53 & 0,08 & 0,07 & 0,03 & 5,45 & 10,25 & 0,90 & 4,30 & 0,82 & 0,08 & 0,70 \\
\hline $\mathrm{CaO}$ & 0,49 & 4,51 & 0,8 & 9,38 & 9,70 & 8,60 & 0,65 & 0,87 & 0,36 & 9,77 & 12,38 & 3,60 & 11,09 & 3,46 & 5,60 & 3,89 \\
\hline $\mathrm{Na}_{2} \mathrm{O}$ & 4,02 & 3,66 & 4,15 & 2,43 & 2,24 & 2,47 & 4,14 & 4,23 & 4,23 & 2,43 & 1,04 & 4,33 & 2,18 & 4,17 & 3,48 & 4,20 \\
\hline $\mathrm{K}_{2} \mathrm{O}$ & 5,26 & 2,58 & 5,06 & 0,21 & 0,36 & 0,31 & 4,84 & 5,01 & 5,14 & 0,22 & 0,14 & 0,28 & 0,19 & 0,14 & 0,09 & 0,16 \\
\hline $\mathbf{P}_{2} \mathbf{O}_{5}$ & $<0,01$ & 0,06 & $<0,01$ & 0,01 & 0,02 & 0,02 & $<0,01$ & $<0,01$ & $<0,01$ & 0,03 & 0,01 & 0,05 & 0,04 & 0,06 & $<0,01$ & 0,07 \\
\hline TOPLAM & 99,90 & 99,86 & 99,90 & 99,79 & 99,81 & 99,81 & 99,91 & 99,89 & $\begin{array}{l}99,89 \\
\end{array}$ & $\begin{array}{l}99,82 \\
\end{array}$ & 99,71 & 99,86 & $\begin{array}{l}99,81 \\
\end{array}$ & $\begin{array}{l}99,95 \\
\end{array}$ & $\begin{array}{l}99,93 \\
\end{array}$ & $\begin{array}{l}99,94 \\
\end{array}$ \\
\hline \multicolumn{17}{|l|}{ İz Element } \\
\hline Ba & 393 & 580 & 313 & 57 & 103 & 98 & 330 & 443 & 18 & 64 & 30 & 141 & 34 & 66 & 9 & 80 \\
\hline Ga & 14,4 & 13,6 & 15,0 & 10,9 & 11,9 & 11,5 & 14,6 & 14,1 & 11,8 & 14,9 & 12,7 & 11,9 & 15,3 & 11,9 & 17,7 & 12,4 \\
\hline Hf & 5,0 & 3,1 & 5,8 & 1,3 & 1,4 & 1,7 & 4,1 & 4,5 & 2,5 & 1,1 & 0,7 & 3,7 & 1,2 & 3,5 & 6,8 & 3,5 \\
\hline Nb & 16,2 & 6,3 & 18,4 & 0,7 & 0,7 & 0,7 & 14,4 & 16,7 & 12,3 & 0,6 & 0,3 & 4,8 & 0,6 & 1,3 & 3,7 & 1,0 \\
\hline $\mathbf{R b}$ & 324,2 & 74,3 & 32,6 & 3,9 & 4,8 & 4,3 & 308,7 & 300,9 & 688,9 & 3,9 & 2,4 & 3,5 & 4,3 & 1,9 & 1,2 & 1,2 \\
\hline $\mathrm{Sr}$ & 141,0 & 270,6 & 141,6 & 121,6 & 131,4 & 111,5 & 137,6 & 183,8 & 7,2 & 173,1 & 139,1 & 277,5 & 207,5 & 170,2 & 188,0 & 187,2 \\
\hline $\mathbf{T a}$ & 0,9 & 0,4 & 0,9 & $<0,1$ & $<0,1$ & $<0,1$ & 0,9 & 0,9 & 1,4 & $<0,1$ & $<0,1$ & 0,4 & $<0,1$ & $<0,1$ & 0,2 & $<0,1$ \\
\hline Th & 32,6 & 6,2 & 35,0 & 0,7 & 0,6 & 0,6 & 27,7 & 22,2 & 25,4 & 0,3 & $<0,2$ & 6,1 & 0,3 & 0,6 & 0,7 & 0,6 \\
\hline $\mathbf{U}$ & 3,7 & 1,2 & 5,2 & 0,2 & 0,2 & 0,2 & 9,8 & 7,8 & 2,7 & $<0,1$ & $<0,1$ & 1,4 & $<0,1$ & 0,3 & 0,2 & 0,2 \\
\hline $\mathbf{V}$ & 10,0 & 74 & 11,0 & 180,0 & 200 & 186,0 & 11,0 & 10,0 & $<8,0$ & 235,0 & 350,0 & 37,0 & 298,0 & 32,0 & $<8,0$ & 40,0 \\
\hline $\mathrm{Zr}$ & 217,5 & 124,0 & 223,3 & 41,5 & 37,8 & 50,0 & 173,8 & 192,3 & 41,0 & 35,8 & 20,0 & 151,4 & 39,5 & 136,1 & 259,2 & 121,5 \\
\hline $\mathbf{Y}$ & 7,9 & 15,2 & 9,7 & 12,3 & 13,1 & 16,3 & 7,9 & 8,4 & 60,1 & 19,8 & 11,3 & 11,2 & 17,9 & 23,8 & 70,8 & 18,9 \\
\hline $\mathrm{Cu}$ & 2,9 & 4,6 & 2,5 & 12,0 & 23,4 & 10,7 & 2,3 & 1,7 & 1,9 & 85,2 & 46,1 & 2,4 & 13,9 & 4,5 & 5,2 & 2,3 \\
\hline $\mathbf{P b}$ & 4,6 & 1,3 & 6,5 & 1,0 & 0,3 & 0,4 & 3,2 & 3,9 & 2,3 & 0,5 & 2,1 & 1,2 & 0,3 & 0,1 & 0,4 & 0,2 \\
\hline $\mathbf{Z n}$ & 25,0 & 16,0 & 74,0 & 12,0 & 14 & 14,0 & 82,0 & 16,0 & 6,0 & 18,0 & 7,0 & 31,0 & 11,0 & 20,0 & 6,0 & 16,0 \\
\hline \multicolumn{17}{|c|}{ Nadir Toprak Element } \\
\hline $\mathbf{L a}$ & 46,5 & 14,1 & 41,2 & 2,9 & 3,6 & 3,9 & 35,4 & 38,3 & 33,8 & 2,2 & 1,3 & 14,5 & 2,7 & 4,6 & 10,2 & 6,7 \\
\hline $\mathrm{Ce}$ & 63,1 & 23,8 & 48,5 & 6,2 & 7,6 & 9,0 & 46,2 & 50,6 & 70,7 & 5,9 & 3,1 & 24,8 & 6,1 & 11,1 & 28,7 & 15,0 \\
\hline $\operatorname{Pr}$ & 4,55 & 2,46 & 3,96 & 0,81 & 1,02 & 1,36 & 3,05 & 4,41 & 7,95 & 1,02 & 0,48 & 2,55 & 1,0 & 1,57 & 4,59 & 2,09 \\
\hline Nd & 11,4 & 9,1 & 10,3 & 3,9 & 4,5 & 6,5 & 8,0 & 11,8 & 27,1 & 5,7 & 3,1 & 9,2 & 5,5 & 7,5 & 22,4 & 8,9 \\
\hline Sm & 1,35 & 1,94 & 1,21 & 1,13 & 1,22 & 1,68 & 0,91 & 1,37 & 5,10 & 1,85 & 1,22 & 1,66 & 1,91 & 2,27 & 7,01 & 2,29 \\
\hline Eu & 0,26 & 0,67 & 0,27 & 0,46 & 0,49 & 0,53 & 0,21 & 0,3 & 0,04 & 0,72 & 0,46 & 0,63 & 0,66 & 0,89 & 1,80 & 0,83 \\
\hline Gd & 1,08 & 2,13 & 1,12 & 1,64 & 1,76 & 2,10 & 0,89 & 1,2 & 5,30 & 2,92 & 1,57 & 1,87 & 2,52 & 3,11 & 9,77 & 2,75 \\
\hline Tb & 0,18 & 0,36 & 0,17 & 0,29 & 0,32 & 0,38 & 0,16 & 0,18 & 1,07 & 0,52 & 0,29 & 0,28 & 0,46 & 0,56 & 1,82 & 0,49 \\
\hline Dy & 1,04 & 2,21 & 1,19 & 1,95 & 2,13 & 2,61 & 0,89 & 1,04 & 7,82 & 3,37 & 1,89 & 1,95 & 2,97 & 3,74 & 11,84 & 2,96 \\
\hline Ho & 0,24 & 0,50 & 0,29 & 0,44 & 0,46 & 0,56 & 0,23 & 0,22 & 1,94 & 0,75 & 0,44 & 0,40 & 0,66 & 0,83 & 2,60 & 0,64 \\
\hline $\mathbf{E r}$ & 0,79 & 1,50 & 0,89 & 1,21 & 1,44 & 1,62 & 0,79 & 0,86 & 5,96 & 2,22 & 1,38 & 1,26 & 1,92 & 2,56 & 7,80 & 2,11 \\
\hline $\mathbf{T m}$ & 0,15 & 0,25 & 0,17 & 0,20 & 0,23 & 0,27 & 0,15 & 0,14 & 1,01 & 0,34 & 0,18 & 0,20 & 0,28 & 0,41 & 1,20 & 0,32 \\
\hline $\mathbf{Y b}$ & 1,12 & 1,66 & 1,49 & 1,33 & 1,52 & 2,02 & 1,08 & 1,14 & 7,51 & 2,08 & 1,27 & 1,47 & 1,91 & 2,93 & 8,02 & 2,31 \\
\hline Lu & 0,21 & 0,28 & 0,25 & 0,22 & 0,25 & 0,32 & 0,21 & 0,21 & 1,16 & 0,32 & 0,18 & 0,25 & 0,31 & 0,47 & 1,29 & 0,40 \\
\hline
\end{tabular}


kayaçların seri karakterlerinin tayininde toplam alkaliler $\left(\mathrm{Na}_{2} \mathrm{O}+\mathrm{K}_{2} \mathrm{O}\right)$ ve silis $\left(\mathrm{SiO}_{2}\right)$ diyagramı kullanılmıştır (Şekil12). Diyagramda da görüldüğü gibi, inceleme alanına ait örneklerin tamamı subalkalen alanında yer almaktadır.

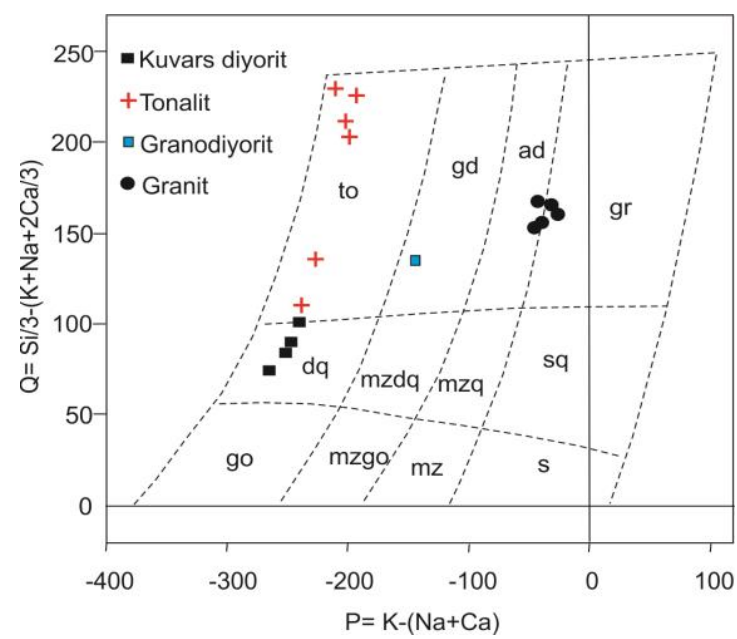

Şekil 11. Çolaklı plütonik kayaçların Debon ve Le Fort [21, 22]'ın Q-P adlandirma diyagramındaki konumları ( to: tonalit, gd: granodiyorit, ad: adamellit, gr: granit, dq: kuvars diyorit, mzdq: kuvars monzo diyorit, mzq: kuvars monzonit, sq: kuvars siyenit, go: gabro/diyorit, mzgo: monzo gabro, mz: monzonit, s: siyenit)

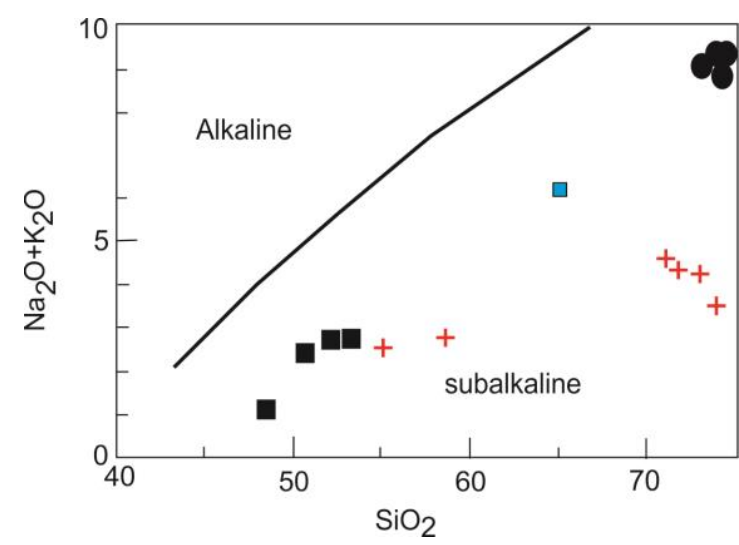

Şekil 12. Çolaklı plütonik kayaçlarına ait örneklerin Alkali-Silis diyagramında dağılımı [23]. (Simgeler Şekil 11 deki ile aynıdır).
Pearce ve arkadaşları [24] tarafından önerilen ve $\mathrm{Nb}$ elementi ile $\mathrm{Y}$ elementinin korelasyonuna dayalı tektono-magmatik diskriminasyon diyagramı volkanik yay granitoyidleri (VAG) ile çarpışmayla eş yaşlı granitoyidleri (Syn-COLG), levha içi granitoydleri (WPG) ve okyanus sırtı granitoyidleri (COLG)'nden ayırmakta kullanılmaktadır. Çalışma bölgesindeki örneklere ait veriler Pearce ve arkadaşları, [24]'nin Nb-Y diyagramına göre değerlendirildiğinde $\mathrm{VAG}$ ve Syn-COLG alanlarında yoğunlaştıkları görülmektedir (Şekil 13).

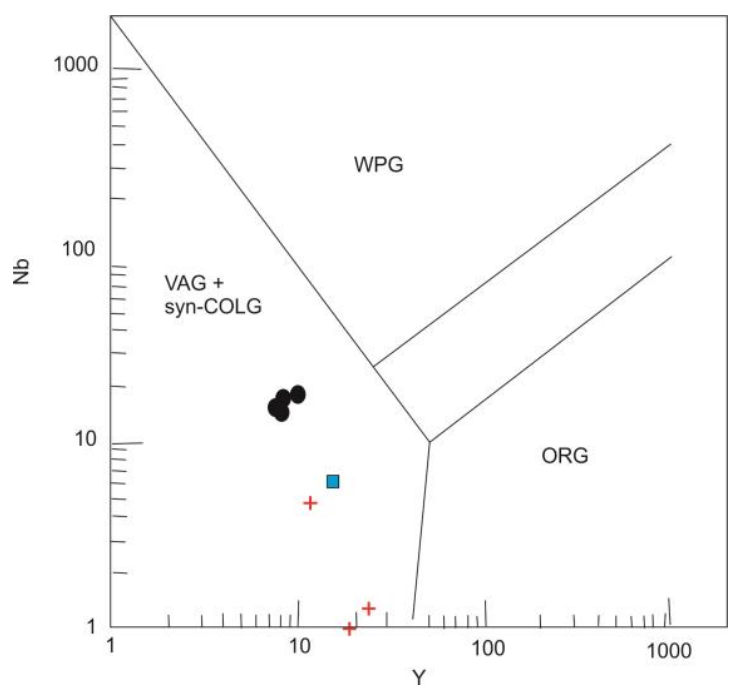

Şekil 13. Çolaklı plütonik kayaçlarının Pearce ve arkadaşları, [24]'nin Nb-Y diyagramındaki dağılımı (ORG: Okyanus Ortas1 Sirtı Granitoyidleri, VAG: Volkanik Yay Granitoyidleri, WPG: Levha İçi Granitoyidleri, COLG: Çarpışma Ürünü Granitoyidleri). (Simgeler Şekil11 deki ile aynıdır).

Chappell ve White (1974) ve White ve Chappell (1977), kıtasal çarpışma kuşaklarında gelişen granitoyidleri; arazi gözlemleri, bazı element ve mineralojik özelliklerine göre I tipi ve $S$ tipi granitoyidler olarak iki gruba ayırmışlardır. Ayrıca bunlara ilave olarak A-tipi (Colins ve arkadaşları, 1982) ve M-tipi (White ve Chappell, 1977) granitoyidler de kıta içi ve okyanusal fay ortamlarını karakterize etmek için kullanılmıştır. Çolaklı Plütonitlerine ait 16 adet kayaç üzerinde 
yapılan Nadir Toprak Element (REE) analiz sonuçları Çizelge 1'de verilmiştir. Bu veriler ışığında hazırlanan Kondrit'e göre normalize edilmiş Nadir Toprak Element (REE) diyagramına bakıldığında Hafif Nadir Toprak Elementleri (LREE) bakımından zenginleşme ve Ağır Nadir Toprak Elementleri (HREE) bakımından ise yatay veya yataya yakın bir trend gözlenmektedir. Ayrıca, bu genel özelliklerin dışında Eu açısından negatif bir anomali izlenmekte olup, bu durum da feldispat fraksiyonlanması ile açıklanabilir (Şekil 14). Ayrıca buna ek olarak hazırlanan Kayaç/İlksel Manto Spider diyagramı'nda (Şekil 15) Rb, Nb, Ti elementlerinde negatif anomali izlenmektedir. Hafif Nadir Toprak Element (LREE) ve Büyük İyon Litofil Elementler (LILE)'ce zenginleşmesi, $\mathrm{U} / \mathrm{Nb}, \mathrm{Th} / \mathrm{Yb}$ değerlerinin yüksek, Nb/La, Ti/Eu oranlarının düşük olması bu kayaçların volkanik yay özelliği taşıdıklarını ve ergime kamasında mantonun dalan kabuktan türeyen akışkanlarca zenginleştiğini (Pearce, 1983) veya kaynak mantonun hafifçe zenginleştiğini göstermektedir.

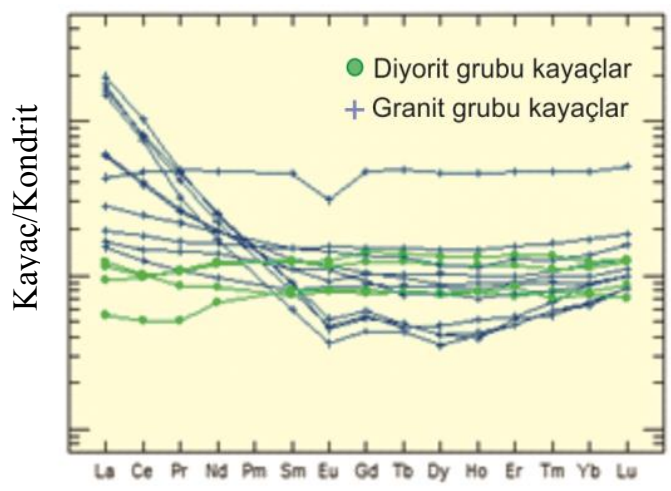

Şekil 14. Çolaklı plütonik kayaçlarının Kondrit'e göre normalize edilmiş Nadir Toprak Element (REE) diyagramı [29].

\section{TARTIŞMA VE SONUÇLAR}

Çalışma alanında Elazı̆̆ Magmatitleri’ne ait olan Çolaklı (Elazığ) çevresindeki plütonik kayaçlar, esas olarak granitik ve diyoritik kayaçlardan oluşmaktadır. İnceleme alanının en yaşlı birimini oluşturan Üst Kretase yaşlı Elazı̆
Magmatitleri'ndeki granitik kayaçlar; granit, granodiyorit ve tonalitler olup, diyoritik kayaçlar ise, diyorit ve kuvars diyoritlerdir. Bölgede granit, tonalit ve diyoritler daha baskın olup, I-tipi granitoyidlerin litolojik ve jeokimyasal özelliklerine sahiptirler. Elazığ Magmatitleri ile ilgili olarak yapılan çalışmalarda granitoyidlerin Itipi granitoyid bileşiminde olduğu konusunda birleşen araştırmacılar kayaçların kökeni hakkında farklı görüşler belirtmişlerdir [20], [9], [30].

Yazgan [20], Malatya-Elazı̆̆ çevresindeki magmatik kayaçlarda yaptığı çalışmalarda, kalkalkalen bileşimli bu kayaçların genç ve kalın olmayan bir kıta kabuğu üzerine yerleşen etkin bir kıta kenarı ürünü olduğunu belirtmiştir. Baskil (Elazı ̆) çevresindeki magmatik kayaçlarda çalışma yapan Akgül, M. [30] ise, bu magmatitlerin granitik ve diyoritik bileşimli olduklarını belirtip, granitlerin çarpışma kökenli, diyoritlerin ise volkanik yay kökenli olduklarını ileri sürmektedir. Araştırmacı, farklı iki kökenli bu magmatitlerin oluşumunun, yitim mekanizmasıyla değil de çarpışma ile açıklanabileceğini belirtmiştir. Bingöl [6] ve Akgül, [9] ise, Elazı ̆̆ Magmatitleri'nin kismen okyanusal, kismen de kıtasal kabuk üzerinde gelişen ada yayı ürünleri olduğunu ileri sürmektedirler. Turan ve arkadaşları'da 'Doğu Toroslar'ın Jeodinamik Evriminin Elazı ̆̆ Civarındaki Özellikleri” konulu çalışmalarında, Elazı ̆̆ Magmatitleri'nin BitlisPütürge masifi ile Keban Metamorfitleri arasında gelişen ve Neotetis'in bir kolu durumunda olan okyanus tabanı ve yay malzemesi ürünü olduğunu belirtmişlerdir [31]. Doğu Toroslar'da inceleme yapan tüm araştırmacilar [32], [20], [5, 6], [33], [34], [7], [35], Arap Levhası ile Anadolu Levhası (Keban-Malatya ve Bitlis-Pütürge Masifleri) arasında Neotetis'in açılmaya başladığını ve Üst Kretase'den itibaren de kuzeye doğru dalması sonucu, okyanus kabuğunun yok olduğunu kabul etmektedirler (Şekil 16). Dalmanın devam ettiği Üst Kretase periyodunda, üstteki okyanusal kabukta oluşan gerilme rejimi sonucunda, yeni okyanusal kabuk oluşumu başlamıştır. Bu zonda oluşan birim ofiyolitleri vermektedir [13], [36]. 


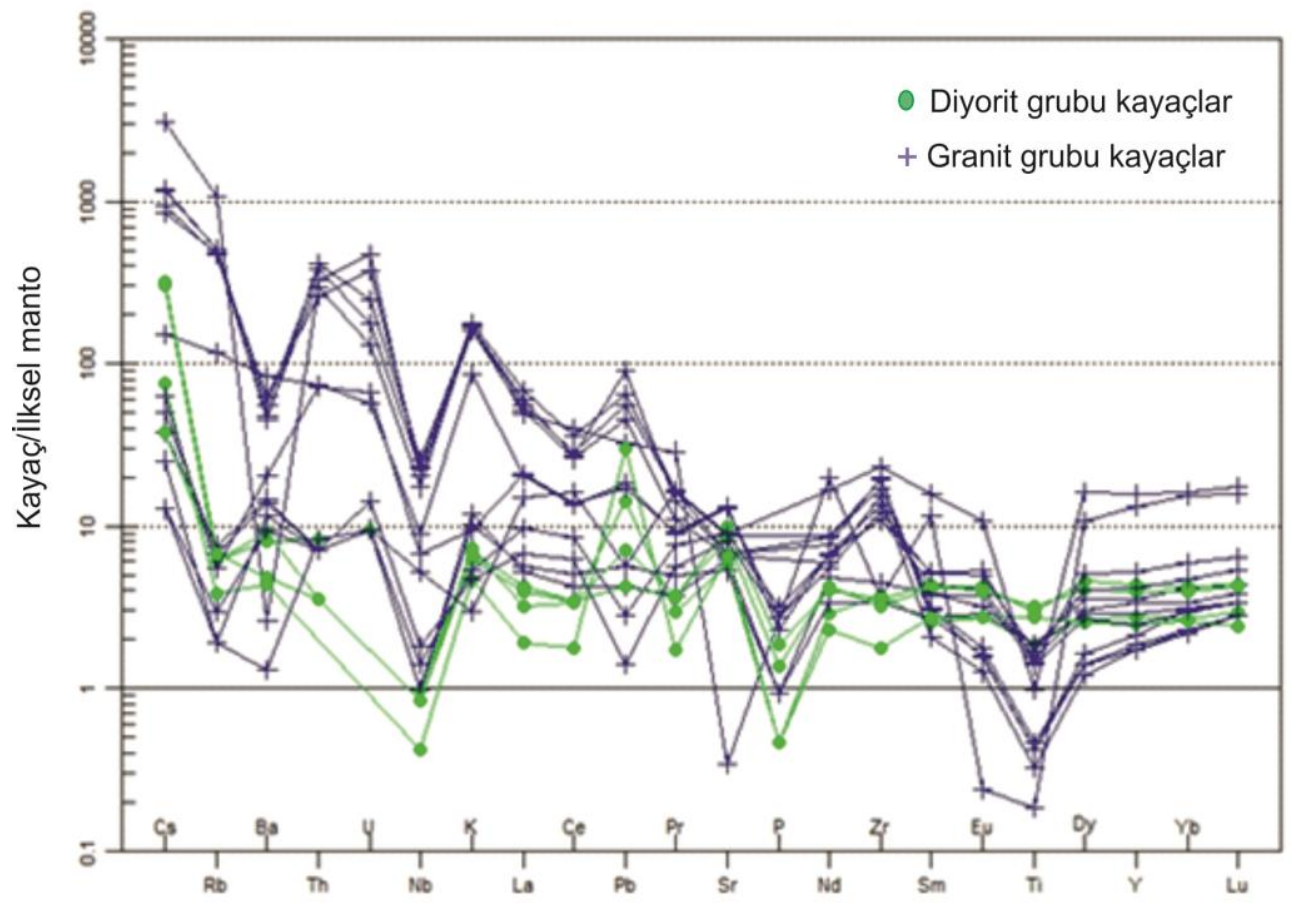

Şekil 15. Elazığ Magmatitleri'ne ait kayaçların Kayaç/İlksel Manto Spider Diyagramı'ndaki dağılımı [29]

Üst Kretase sonuna doğru, bu yeni okyanus kabuğu üzerinde gelişmeye başlayan bir ada yayı izlenmektedir. $\mathrm{Bu}$ yay ürünleri de Elazı̆̆ Magmatitleri'ni vermiștir. Oluşan kayaçlar, K-G yönlü sıkışma sonucunda, kuzeydeki Anadolu Levhası'nın güneye doğru ada yayı üzerine itilmesi ve parçalanarak Bitlis-Pütürge ve Keban-Malatya Masifleri olarak ayrılması ve buna bağlı olarak kabuk kalınlaşması sonucu, yüksek $\mathrm{H}_{2} \mathrm{O}$ basıncı ve sicaklıklarda gabroların metamorfize olması ve daha sonra kısmi ergimeye uğraması ile oluşan eriyik kısmen kabuğun üst kesimlerindeki gabrolar ve üstteki ada yayı malzemesi içerisine sokulduğu gabroların metamorfizmasina ve amfibolitlerin oluşumuna neden olmaktadır [36]. Üst Kretase sonuna doğru üst levhadaki ofiyolitler, ada yayı malzemeleri (Elazığ Magmatitleri) ve KebanMalatya Metamorfitleri güneye doğru itilmişlerdir. Ancak, tüm birimler, bugünkü konumlarını Alt
Miyosen sonrası Doğu Toroslar'daki bindirmelere bağlı olarak almışlardır [36]. Sonuç olarak, elde edilen veriler 1şı̆̆ı altında, Çolaklı (Elazığ) çevresindeki plütonik kayaçlardaki iz elementler ve Nadir Toprak Element (REE) konsantrasyonları, bu kayaçların dalan levhadan türeyen akışkanlarca zenginleşmiş bir kaynaktan oluştuğunu, Ağır Nadir Toprak Elementler (HREE) ve HFS elementlerin düşük değerlerde olması ise, bu kaynağın tüketilmiş bir manto kaynağı olduğunu vermektedir. Litolojik ve jeokimyasal veriler ile daha önce yapılmış çalışmalara göre; Çolaklı (Elazığ) çevresi plütonik kayaçlarının Üst Kretase sonlarına doğru gelişmeye başlayan bir ada yayını veren subalkalen karakterli yitim ile ilişkili bir magmanın ürünü olduğunu ve Alt Miyosen sonrası tektonik hareketlerle bugünkü konumlarını aldıkları söylenebilir. 

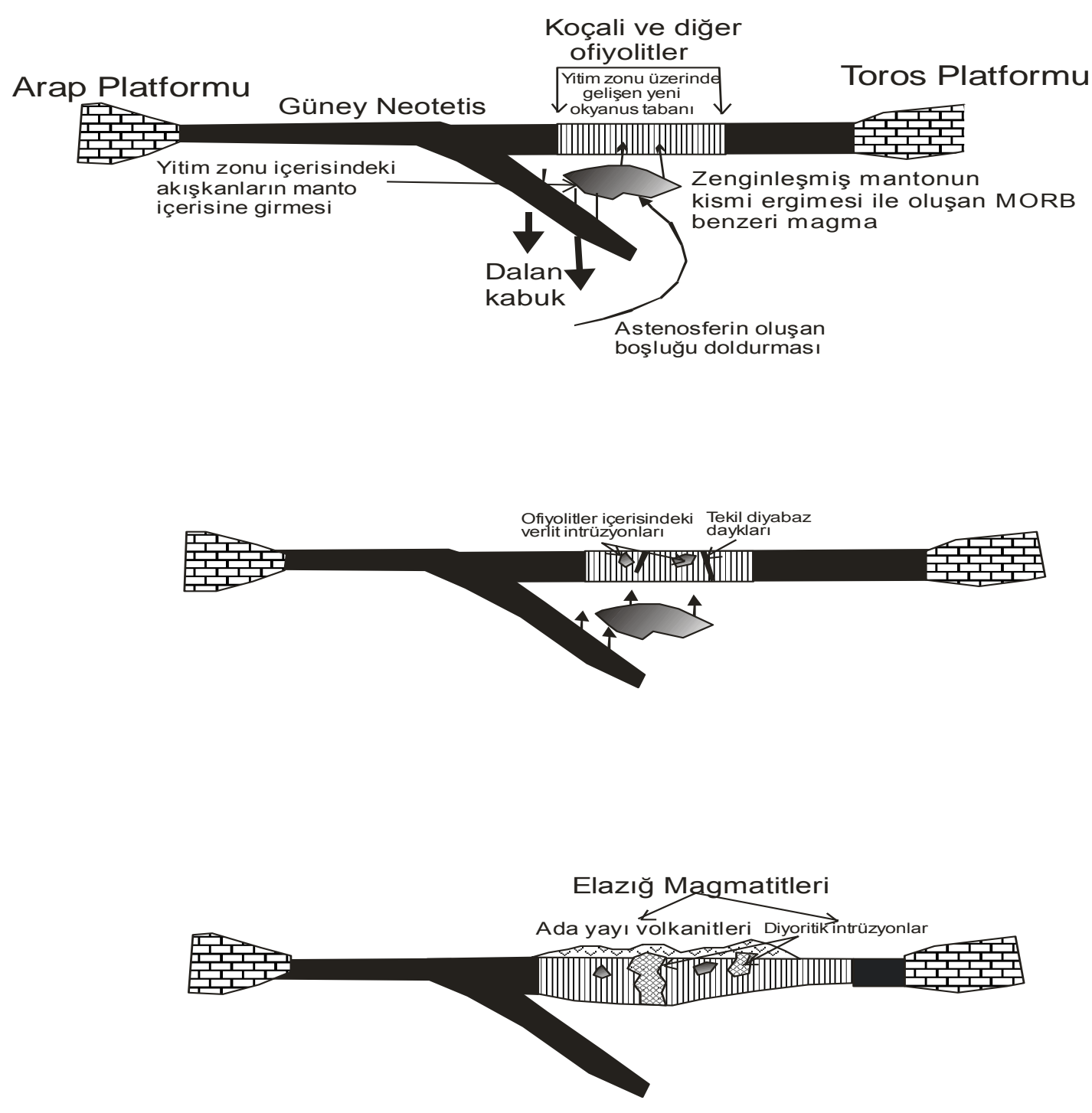

Şekil 16. Elazığ Magmatitleri'nin oluşumunu gösteren tektono-magmatik model [37] 


\section{KAYNAKLAR}

1. Perinçek, D., 1979a. Palu-Karabegan-ElazığSivrice-Malatya Alanının Jeolojisi ve Petrol İmkanlar1. T.P.A.O. Rapor No: 1361.

2. Perinçek, D., 1979b. The geology of HazroKorudağ - Çüngüş-Maden - Ergani - HazarElazı̆̆ - Malatya Area. Guide Book, T.J.K. yayını, 33s.

3. Perinçek, D., 1980a. Arabistan Kıtası Kuzeyindeki Tektonik Evrimin, Kita Üzerinde Çökelen İstifteki Etkileri. Tür. 5. Petrol Kong., Tebligler, 77-93.

4. Perinçek, D., 1980b. Bitlis Metamorfitleri'nde Volkanitli Triyas. T.J.K. Bült., 23, 201-211.

5. Bingöl, A.F., 1982. Elazı̆̆-Pertek-Kovancılar Arası Volkanik Kayaçların Petrografik İncelenmesi. F.Ü. Fen Fak. Derg., 1, 9-21.

6. Bingöl, A.F., 1984. Geology of the Elazığ Area in the Eastern Taurus Region. In Tekeli, O. and Göncüoğlu, M.C., eds., "Geology of the Taurus Belt", p.209-217.

7. Bingöl, A.F., 1988. Petrographical and Petrological Features of Intrusive Rocks of Yüksekova Complex in the Elazığ region (Eastern Taurus-Turkey). Journ. F.Ü., 312, 117.

8. Turan, M., 1984. Baskil-Aydınlar (Elazığ) Yöresinin Stratigrafisi ve Tektoniği. Doktora Tezi, F.Ü. Fen Bilimleri Enst. 185s. (yayınlanmamış).

9. Akgül, B., 1993. Piran Köyü (Keban) Çevresindeki Magmatik Kayaçların Petrografik ve Petrolojik Özellikleri. Doktora Tezi, F.Ü. Fen Bilimleri Enst., 125s. (yayınlanmamış).

10. Turan, M., 1993. Elazığ ve Yakın Civarındaki Bazı Önemli Tektonik Yapılar ve Bunların Bölgenin Jeolojik Evrimindeki Yeri. A. Suat Erk Jeoloji Sempozyumu, Bildiriler, Ankara Üniv. Fen Fak., 193-204, Ankara.

11. İnceöz, M., 1994. Harput (Elazığ) Yakın Kuzeyi ve Doğusunun Jeolojik Özellikleri. Doktora Tezi, F.Ü. Fen Bilimleri Enst. 112s.

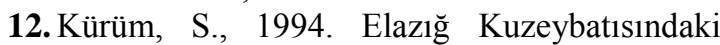
Genç Volkanitlerin Petrolojik Özellikleri. Doktora Tezi, F.Ü. Fen Bilimleri Enst., 107s. (yayınlanmamış).
13. Bingöl, A.F., Beyarslan, M., 1996. Elazı̆g Magmatitleri'nin Jeokimyası ve Petrolojisi. K.T.Ü. 30. Y1l Sempozyumu Bildiri Metinleri. s.208-224.

14. Beyarslan, M., 2000. Serince-Harput (Elazığ) Çevresindeki Granitik Kayaçlar ve Kökeni. Geosound, 37, 105-116.

15. Perinçek, D., Özkaya, İ., 1981. Arabistan Kıtası Kuzey Kenarının Tektonik Evrimi. H.Ü. Yerbilimleri Derg., 8, 91-101.

16. Turan, M., Bingöl, A.F., 1991. KovancılarBaskil (Elazı̆̆) Arası Bölgenin Tektonostratigrafik Özellikleri. Ç.Ü. Ahmet ACAR Jeoloji Sempozyumu, Tebligler, 213227.

17. Beyarslan, M., 1991. İspendere (Kale-Malatya) Ofiyolitlerinin Petrografik Özellikleri. Yüksek Lisans Tezi, F.Ü. Fen Bilimleri Enst., 57s. (yayınlanmamış).

18. Bingöl, A.F. ve Beyarslan, M., 1995. Elazı $\breve{g}$ Magmatitleri'nin Jeokimyasi ve Petrolojisi. K.T.Ü. 30. Y1l Sempozyumu Bildiri Özleri. s.15.

19. Beyarslan, M., 1996. Kömürhan Ofiyolit Biriminin Petrografik ve Petrolojik İncelenmesi. Furat Üniversitesi Fen Bilimleri Enstitüsü., Elazığ Doktora Tezi, 103s.

20. Yazgan, E., 1981. Doğu Toroslar'da Etkin Bir Paleokıta Kenarı Etüdü (Üst Kretase-Orta Eosen) Malatya-Elazığg, Doğu Anadolu: H.Ü. Yerbilimleri Derg., 7, 83-104.

21. Debon, F., Le Fort, P., 1982. A ChemicalMineralogical Classification of Common Plutonic Rocks and Associations, Transactions of the Royal Soc. Edingburgh. Earth Sci. 73, 135-149.

22. Debon, F., Le Fort, P., 1988. A Cationic Classification of Common Plutonic Rocks and their Magmatic Associations: Principles, Method, Applications. Bull. Miner. 111, 493510 .

23. Irvine, T.N., Baragar, W.R.A., 1971. A Guide to the Chemical Classification of the Common Volcanic Rocks. Canadian Journal of Earth Sciences, 8, 523-548.

24. Pearce, J.A., Harris, N.B.W., Tindle, A.G., 1984. Trace Element Discrimination Diagrams for the Tectonic Interpretation of Granitic Rocks. J. Petrol. 25, 954-983. 
25. Chappell, B.W., White, A.J.R., 1974. Two Contrasting Granite Types, Pacific Geology, 8, 173-174.

26. White, A. J. R. and Chappell, B. W., 1977. Ultrametamorphism and Granitoid Genesis. Tectonophysics, 43, 7-22.

27. Collins, W.J., Bams, S.D., White, A.J.R. ve Chappell, B.W., 1982. Nature and Origin of AType Granites with Particular Reference to South Eastern Avustralia. Con trib. Mineral. Petrol., 80, 189-200.

28. Pearce, J.A., 1983, Role of the Sub-Continental Lithosphere in Magma Genesis at Acrive Continental Margins: p. 230-249 in, Hawkesworth, C.J. and Norry, M.J., eds., Continental Basalts and Mantle Xenoliths, Shiva Publishing Ltd., Cambridge, Mass., $272 \mathrm{p}$.

29. Sun, S., Mc Donough, W.F., 1989. Chemical and Isotopic Systematic of Oceanic Basalts. Implications for Mantle Compositionand Processes. In: Saunders, A.D., Norry, M.J. (eds.), Magmatism in the Ocean Basins, Special Publication 42. Geological Society of London, $312 \mathrm{pp}$.

30. Akgül, M., 1991. Baskil (Elazı̆̆) Granitoyidinin Petrografik ve Petrolojik Özellikleri. Yerbilimleri Geosound, 18, 67-78.

31. Turan, M., Bingöl, A.F. ve Aksoy, E., 1993. Doğu Toroslar'ın Jeodinamik Evriminin Elazığ Civarındaki Özellikleri. H.Ü. Yerbilimleri 25. yılı Sempozyumu, Ankara.

32. Ricou, L. E., Argyriadis, I., Marcoux, J., 1975. UAxe Calcaire du Taurus Un Alignement de Fenetres Arabo-Africains Sous des Nappes Radiolaritiques, Ophiolitiques Et Metamorphiques. Bull. Soc. Geol. Fr., Ser. 7, 17, 1024-1044.

33. Şengör, A.M.C., Yılmaz, Y., 1983. Türkiye'de Tetis'in evrimi; Levha Tektoniği Açısından Bir Yaklaşım. TJK Yerbilimleri Özel Dizisi, No. 1, $75 \mathrm{~s}$.

34. Michard, A., Whitechurch, H., Ricou, L.E., Montigny, R., Yazgan, E., 1985. Tauric Subduction (Malatya-Elazig Province) and Its Bearing on the Tectonics of the Tethyan Realm in Turkey. In: Dixon JE, Robertson AHF (eds) The Geological Evolution of the Eastern
Mediterranean. Geol Soc Spec Publ Lond, 361-373.

35. Yılmaz, Y., Yiğitbaş, E., Genç, Ş. C, 1993. Ophiolitic and Metamorphic Assemblages of Southeast Anatolia and Their Significance in the Geological Evolution of the Orogenic Belt. Tectonics, 12(5), 1280-1297.

36. Beyarslan, M., Bingöl, A. F., 2000. Petrology of a Supra-Subduction Zone Ophiolite (Elazı̆̆ Turkey). Can. J. Earth Sci., 37, 1411-1424.

37. Beyarslan M., Bingöl A.F., Rizeli M.E., 2014. Koçali (Adıyaman) Ofiyolitindeki Manto Peridotitlerinin Jeokimyası (Ana Oksitler, İz Elementler, Platin Grubu Elementler) ve Petrolojisi, Proje No: MF.12.35. 
